\title{
CONSUMERS' ATTITUDES, KNOWLEDGE AND CONSUMPTION OF PRODUCTS WITH NUTRITION AND HEALTH CLAIMS ${ }^{1}$
}

\author{
Sanja Mitić2 , Mirjana Gligorijević3
}

\begin{abstract}
Summary
The paper presents the selected results of consumers' study of food products in Serbia. It focuses on the products with nutrition and health claims (NHCs) and the analysis of the main consumers' characteristics which influence their awareness and knowledge about NHCs, their attitudes toward products with NHC and their purchase intentions. Different socio-demographic factors that influence consumers 'behavior were investigated. Education, gender, age and income of the respondents are the key factors which influence awareness, knowledge and consumption. As those products are closely related to consumers' health, we presented the results based on the differences in health status of the respondents. Main findings show that the respondents with health problems do not consume those products as often as others, which is the outcome of a low level of nutrition knowledge. This represents a major restraining factor for the increase in consumption. After identifying the characteristics of demand, we have suggested some proposals for managers, aimed at overcoming the identified problems, and for government institutions so as to obtain a proactive approach to improving the overall health of the population.
\end{abstract}

Key words: health claim, nutrition claim, food labels, nutrition knowledge, consumer behavior.

JEL: $118, M 31, Q 13$

\section{Introduction}

Public health and healthy nutrition concerns represent a significant political and economic matter in developed countries, whereas in the underdeveloped countries they constitute existence issues. Food has become the main issue in public debates and in political activities. Consumers' trust in food producers and authorities to protect them has eroded. This is the consequence of a widespread suspicion and the lack of important information related to food labeling.

1 The paper is a part of a research within the project no. III 41030, supported by the Ministry of Science and Education of the Serbian Government.

2 Sanja Mitić, Ph.D., Assistant Professor, Faculty of Economics, Belgrade University, Kamenička Street no. 6, Belgrade, Serbia, Phone: +381 11302 11 75, E-mail: sanja@ekof.bg.ac.rs

3 Mirjana Gligorijević, Ph.D., Full Professor, Faculty of Economics, Belgrade University, Kamenička Street no. 6, Belgrade, Serbia, Phone: +381 113021 019, E-mail: miragli@sezampro.rs

EP 2015 (62) 2 (335-352) 
This paper focuses on consumers' perception and attitudes toward food labels, with the focal point on nutrition and health claims. Nutrition and health claims (NHCs) should have a positive influence on consumers' perception of the effects of food products on their health, as well as on the changes in consumption patterns and diet preferences.

The main aim of this study is to examine the characteristics of the demand for NHCs product market in Serbia. Several major aspects shall be examined: consumers' awareness of products with NHCs, nutrition knowledge, attitudes toward nutrition and health labeling, attitudes toward products with NHCs and the consumption of those products. As it is shown in the literature, those are important variables that explain consumers' behavior regarding products with NHCs. This paper is organized into five parts. The section following the introduction presents the literature review concerning consumers' food choice behaviors and studies that deal with nutrition and health claims issues. We will define nutrition and health claims, based on the EU regulations, pointing out several major contributions from international studies and describing key findings of researches conducted within Serbian market. After that, methodology of the research will be presented and followed by main research findings regarding consumers' awareness, knowledge, attitudes and consumption of products with NHCs. In the final section, we will discuss the findings and policy, and managerial implications of the results.

\section{The literature review}

The most important point for developing successful marketing strategies in the food sector is understanding the diversity of consumer needs and motives. There are three functions of food: a nutritional function, which is essential for human survival, a sensory function which involves both flavor and texture meant to satisfy sensory needs, and physiological functions such as biorhythm regulation, aging control, the immune system, and body defense (Shimizu, 2003).

The global food market is confronted with a number of ongoing challenges. The key challenges are the rise of health concerns and global obesity epidemic, especially in the developed countries. Producers and retailers are in a position to revise their strategies in order to meet and satisfy changing consumer needs and global market development trends. The trends in the demand for food are shaped by demographic changes and evolving consumer lifestyles. The most important demographic changes are the ageing population, urbanization, smaller households, a rising number of women who work and declining birth rates. At the same time, there is an ongoing trend of a healthy lifestyle and healthy nutrition within which some groups of consumers have a tendency to substitute traditional food products with the healthier ones.

Food choices determine consumers' nutrient intake and influence food production systems. A food choice is a complex process that involves many different factors, including sensory and non-sensory characteristics. Individual food consumption and buying choice can be explained by various factors, such as household and individual characteristics, ability to process information and valuation of health. Sanlier and Karakus (2010) emphasize that there 
are two factors that affect the food choices of consumers: (1) consumer-related factors which include health considerations, sensory variables, social interactions, familiarity and habit, psychographics and demographics; and, (2) the most important, market-related issues which include price, distribution and promotion.

There is a lot of research in literature regarding various factors influencing eating habits and preferences. Most of them emphasize the importance of socio- demographic and economic factors in an attempt to explain consumer food behavior. In Western countries, women eat more healthily than men (Næs et al., 2001), and highly educated people more than less educated people (Niva, 2006). Regarding age, studies show that older people are more willing to adopt eating habits in accordance with recommendations than young people (Niva, 2006). What is more, concerns about health in general and healthy eating increase with age. Also the presence of children in the family influence nutritional quality of diet (Niva, Mäkelä, 2005; Roos, 1998). Based on the basic proposal in the identified studies, mainly conducted in the developed countries, we want to explore the influences of socio-demographic factors in the case of Serbia, with the focus on products with special forms of nutrition and health labeling.

Food labeling, as an important factor of consumers' decision-making, has received a lot of attention in the literature. Labels on food products are used as a marketing instrument in order to ensure effective market positioning related to health issues. Using various types of food labels, producers are oriented toward communicating positive health influences of their products and the promotion of a healthy lifestyle. As a basic type of food labels we have recognized nutrition and health claims, based on the EU regulations. Due to the EU regulation 1924/2006, a nutrition claim is the claim which states or implies that food has particular beneficial nutritional properties due to the energy and/or nutrients or other substances it provides/contains, provides/contains in reduced or increased level, or does not provide/contain (Article 2, REG. (EC) No 1924/2006). A health claim is defined as a statement that shows that the relationship between food or particular ingredient and health exists. There are three types of health claims: (1) functional claims (describe: " the role of a nutrient or other substance in a) growth, development and functions of the body; (b) psychological and behavioral functions; or (c) slimming or weight control" (Article 13, REG. (EC) No 1924/2006)), (2) risk reduction claims ("claims that state, suggest or imply that the consumption of a food category, a food or one of its constituents significantly reduces a risk factor in the development of a human disease", (Article 2, REG. (EC) No 1924/2006)) and (3) health claims referring to children's development.

Nutrition and health claims should have a positive influence on consumers' perception of health effects of food products and on changes in consumption patterns and diet preferences. We can identify several positive influences of food labels, regarding a higher sale of a particular product, as well as the product category. Also, consumers are better informed about food characteristics and influences of some nutrients on health and/or a specific function of the body. Food labels can improve consumers' nutrition knowledge, which is a significant factor in diet changes, in order to maximize health benefits, which is especially important for consumers with some health related problems. In the literature we can find many studies that provide empirical evidence of a positive impact of the food label usage 
on the consumer food choice and purchasing behavior (Shine et al., 1997; Ford et al., 1996; Chan et al., 2005; Baltas, 2001). Regarding the researches on nutrition and health claims, the main conclusion is that consumers value products with claims more than products with no claims, and prefer them (Lalor et al., 2010). Moreover, both health claims and nutrition information influence beliefs about product healthfulness (Ford et al., 1996). Kozup and associates (2003) found that favorable nutrition information or health claims result in consumers more favorable attitudes toward the product, nutrition attitudes, and purchase intentions. On the other hand, some consumers often see claims as a form of promotion and this is why some studies show that consumers rely more on the nutrition panel than claims. The scientific literature in this field is mostly based on studies conducted in the USA and other developed countries in the EU.

In recent years there have been some studies that look into the issue of consumer behavior in food market in Serbia, primarily in the area of motives for the food choice, based on Food Choice Questionnaire (Milošević et al., 2012; Gagić et al., 2014). As regards studies that address the issue of products with health and/or nutrition claims in Serbia, there are several important contributions. Žeželj and associates (2012) explored the impact of the food choice motive, nutrition knowledge and usage of food labels on the attitude toward the food with health claims in six Western Balkan countries. The main results are in accordance with the findings of the studies in western European countries. Nutrition knowledge of consumers as well as trust in labels and the usage of information on labels in the process of decision-making were identifies as the main influences on consumers' attitudes toward the food and health claims.

Apart from quantitative researches, there are some qualitative studies addressing the issue of Serbian consumers $>$ perception of the products with a nutrition and health claim. Based on focus groups, Mitić and Gligorijević (2012) found that, in general, consumers in Serbia understand the link between food and health, but they expressed a certain level of skepticism toward nutrition and health claims on food products. There are differences among various consumers groups regarding the attitudes toward food labels. The most important one is the difference between the respondents with different health status, due to a lower level of understanding and usage of food labels in the case of the respondents with health problems.

Another relevant area of research regarding the food with nutrition and health claims (NHCs) deals with the regulatory issue concerning product labeling and usage of nutrition and health claims by producers. In the EU, USA, Japan and other developed countries there are strict rules for using health and nutrition claims on food products. ${ }^{4}$ In Serbia, the regulatory

4 Aiming to ensure greater clarity and certainty for economic operators, EU Commission issued guidelines for the implementation of specific conditions for health claims, regarding prohibition of unauthorised health claims, mandatory information accompanying authorised health claims, reference to general, non-specific health benefits and the rules for applications concerning the use of generic descriptors (denominations), (European Commission, Health and nutrition claims, http://ec.europa.eu/food/food/labellingnutrition/claims/index_en.htm) 
framework of food labeling does not address the issue of health claims, while the policy concerning nutrition claims is not fully harmonized with the EU legislation.

This regulatory issue in Serbian market was not widely examined in academic studies. In general, the absence of regulatory framework can influence the development of NHCs food market, and the presence of a negative impact of false and misleading claims on consumer skepticism, which has already been identified in the case of Serbian consumers (Mitić, Gligorijević, 2012). The absence of the legislative provides a lot of space for an excessive usage of various nutrition and health claims on food products in Serbia. Numerous health claims are in use (especially risk reduction claims in two groups of products: juices and cereals) without any scientific verification, which undermines the value and importance of health claims in general (Mitić et al., 2013). The lack of legislative in the area provides an opportunity for producers to manipulate consumer choice, by using non-specific, general health claims (Stojanović, Dragutinović Mitrović, 2012) that are imprecise and incomplete. Comparing to other Western Balkan countries, NHCs food product market in Serbia is underdeveloped and producer rather than consumer driven (Stojanović et al., 2010), possibly due to a high level of consumers' skepticism.

The main aim of this study is to examine the characteristics of the demand for NHCs product market. Based on the identified shortcomings in the literature regarding consumers' role in the developing NHCs product market in Serbia, we wanted to identify the influences of consumers' characteristics on their awareness and knowledge about NHCs, their attitudes toward products with NHC and their purchase intentions. Identifying the main distinctions between consumers with different attitudes and purchase intentions can help in discovering the main barriers and obstacles in further development of the market. This is especially important for individuals with some health problems, having in mind that those products can have a positive influence on health and functioning of the human body.

\section{Methodology}

We conducted a survey within a sample of 913 respondents in Serbia, during 2013. We used the Kish grid as the sampling technique. The questionnaire was structured into several parts, addressing consumers' preferences toward food, food labels, traditional food products and products with nutrition and health claims. In this paper we will examine only specific aspects of consumers' attitudes toward products with nutrition and health claims. We used the results of Food Choice Questionnaire and the results regarding consumers' attitudes toward food labels (whether they read labels regularly and whether they believe in their truthfulness) from the first two parts of the questionnaire in order to discuss the results. Basic structural elements of the sample are presented in Table 1 below. 
Table 1. Demographic characteristics of the sample

\begin{tabular}{|c|c|c|c|}
\hline \multicolumn{2}{|c|}{ Characteristics of respondents } & $\begin{array}{c}\text { Number of } \\
\text { respondents }\end{array}$ & $\%$ of respondents \\
\hline \multicolumn{2}{|l|}{ Total } & 913 & 100 \\
\hline \multirow{2}{*}{ Gender } & Female & 492 & 53.9 \\
\hline & Male & 420 & 46.1 \\
\hline \multirow{3}{*}{ Age } & Younger than 30 & 185 & 20.3 \\
\hline & Aged between 30 and 55 & 405 & 44.4 \\
\hline & Older than 55 & 323 & 35.4 \\
\hline \multirow{5}{*}{ Education } & No education & 20 & 2.21 \\
\hline & Primary education & 130 & 14.33 \\
\hline & Secondary education & 516 & 56.89 \\
\hline & Higher education & 83 & 9.15 \\
\hline & High education & 158 & 17.42 \\
\hline \multirow{6}{*}{$\begin{array}{l}\text { Household } \\
\text { income }\end{array}$} & No income & 26 & 2.86 \\
\hline & Less than $20.000 \mathrm{rsd}$ & 96 & 10.56 \\
\hline & Between 20.000 and 40.000 rsd & 237 & 26.07 \\
\hline & Between 40.000 and 80.000 rsd & 340 & 37.4 \\
\hline & Between 80.000 and 120.000 rsd & 150 & 16.5 \\
\hline & More than $120.000 \mathrm{rsd}$ & 60 & 6.6 \\
\hline
\end{tabular}

Source: Authors' calculation according to data from Mitić, Gligorijević, 2013.

Apart from the demographic information about the respondents, we also collected the information about the health status of the respondents. As the topic of health and nutrition characteristics of products is closely connected to human well-being and health, we introduced two additional questions: (1) do the respondents have a chronic illness and (2) what is their overall health status, self-evaluation on a 5-item scale (very bad health, bad health, average health, good health, excellent health).

The structure of the sample regarding health related questions shows that $34 \%$ of the respondents have a chronic health problem ( $66 \%$ of the respondents did not report a chronic illness), while the frequencies for the overall health status are presented in Table 2.

Table 2. Overall health status of the respondents

\begin{tabular}{|l|r|r|}
\hline 5-item scale & Number of respondents & \% of respondents \\
\hline very bad health & 4 & 0.4 \\
\hline bad health & 35 & 3.8 \\
\hline average health & 335 & 36.8 \\
\hline good health & 417 & 45.8 \\
\hline excellent health & 120 & 13.2 \\
\hline
\end{tabular}

Source: Authors' calculation according to data from Mitić, Gligorijević, 2013.

The results are presented based on descriptive statistics with some statistical testing, and factor analysis. 


\section{Results}

Consumers' behavior regarding products with nutrition and health claims is examined in four parts: (a) awareness and knowledge, (b) perceived importance of nutrition and health labeling, (c) attitudes toward products with nutrition and health claims, and (d) consumption of products with nutrition and health claims (actual consumption and intention to consume).

\section{Awareness and knowledge}

Consumers' awareness of the products with NHCs represents an important antecedent of nutrition knowledge (Bornkessel et al., 2014). Awareness and nutrition knowledge can influence attitudes and the level of consumption of those products. Regarding consumer's awareness of products with $\mathrm{NHC}$, we found that $30 \%$ of the respondents are not wellinformed about the products with nutrition and health claims, while only $15 \%$ find themselves very well-informed about those products. Majority of the respondents (45.5\%) expressed a medium level of awareness of the products with nutrition and health claims. Statistically significant differences exist between the respondents in terms of their socio-demographic characteristics and health status. The most important differences in socio-demographic factors are concerned with gander, age, economic status, and level of education.

Women show higher awareness of those products than men $(\mathrm{t}=-3.519, \mathrm{p}=0.000)$, as well as the respondents from households with higher economic standard $(\mathrm{F}=3.715, \mathrm{p}=0.002)$, respondents with higher level of education $(\mathrm{F}=14.073, \mathrm{p}=0.000)$ and respondents younger than 30 (in comparison with the respondents in the middle age group, ages between 30 and 55 , and the oldest ones, who express a lower level of awareness $)(\mathrm{F}=8.593, \mathrm{p}=0.000)$. Those results are comparable with the result of some similar studies carried out in the developed countries (Bornkessel et al., 2014).

Regarding health status, we also found relevant differences in two sections: (i) the respondents that have a chronic illness (in further text we will call them the vulnerable group of the respondents) express a lower level of awareness than others (statistically significant differences: $\mathrm{t}=2.316, \mathrm{p}=0.021$ ); (ii) based on self-evaluated overall health, we found statistically significant differences among five groups of respondents (respondents with very bad health, bad health, average health, good health, excellent health $(\mathrm{F}=8.467, \mathrm{p}=0.000)$; again, the respondents with better health are more aware of products with NHCs.

The results related to the health status of the respondents are alarming. As those products can have a positive impact on health, it is important to increase consumers' level of awareness.

The second group of questions is dedicated to nutrition knowledge. Consumers' knowledge about food represents an important determinant of food choice. In the case of products with nutrition and health claims, nutrition knowledge is the most important, as knowledge about the characteristics of some nutrients, their natural sources and their impact on health. We evaluated knowledge with the help of 10 questions (see table 3), regarding the influence of some nutrition ingredients on health (vitamin D, C, folic acid, salt, polyunsaturated and saturated fats), sources of nutrients (vitamin D, folic acid, polyunsaturated fats) and their role 
in metabolic processes (vitamin A, carbohydrates, calcium).

In general, respondents express a low level of knowledge. Only $3 \%$ of the respondents had more than seven correct answers, $25 \%$ of the respondents answered correctly on less than five questions (10\% answered correctly on 2 or 3 questions). Most of the respondents are in the group of those with 5 or 6 correct answers (48\%). Nutrition knowledge differs in the case of different socio-demographic characteristics of respondents. There are statistically significant differences regarding age and education of the respondents, household income, but also regarding the health status of the respondents or their family members. Among the oldest respondents we found the largest share of those with a low level of nutrition knowledge, while the highest level of knowledge was demonstrated by the middle age group (the respondents between 30 and 55 years) $(\mathrm{F}=4.138, \mathrm{p}=0.016)$. Nutrition knowledge is positively related to the level of education $(\mathrm{F}=8.588, \mathrm{p}=0.000)$, as well as to household income $(\mathrm{F}=5.895, \mathrm{p}=0.003)$.

Table 3. Nutrition knowledge

\begin{tabular}{|l|r|}
\hline \multicolumn{1}{|c|}{ Questions } & \multicolumn{1}{c|}{$\begin{array}{c}\text { \% of correct } \\
\text { answers }\end{array}$} \\
\hline 1. Vitamin A helps in Calcium absorption. & $49.4 \%$ \\
\hline 2. Vitamin C is a good treatment for a cold. & $98.7 \%$ \\
\hline 3. Folic acid helps in fighting leukemia. & $48.5 \%$ \\
\hline 4. Vitamin D helps fight osteoporosis & $81.3 \%$ \\
\hline 5. Carbohydrates turn to sugar and nourish the body. & $75.4 \%$ \\
\hline 6. Polyunsaturated fats increase cholesterol levels more than saturated fats. & $4.3 \%$ \\
\hline 7. High blood pressure risk can probably be reduced with low sodium diet. & $95.4 \%$ \\
\hline 8. Folic acid is found in root vegetables. & $4.6 \%$ \\
\hline 9. Vitamin D is found in milk. & $73.4 \%$ \\
\hline 10. Polyunsaturated fatty acids are found in olive oil. & $60.1 \%$ \\
\hline
\end{tabular}

Source: Authors' calculation according to data from Mitić, Gligorijević, 2013.

When it comes to health status, we have similar results as in the previous section. The group of respondents with some chronic health problems (the vulnerable group) express a lower level of nutrition knowledge than the respondents without a chronic illness $(\mathrm{F}=4.995$, $\mathrm{p}=0.007)$. Also, there is a similar relationship between self-evaluated overall health status and nutrition knowledge. Those results were not expected. As an outcome of health problems, we expected that the respondents would show a higher interest in nutrition, especially the respondents with chronic illnesses whose therapy is closely connected with changes in their lifestyle and nutrition. Conversely, in our sample, respondents with no health problems expressed better nutrition knowledge as well as a higher level of awareness of products with NHCs. There are two possible explanations. Firstly, that better health status is connected with a more balanced nutrition as an outcome of a better nutrition knowledge and awareness of products with NHCs. The second explanation is based on the socio-economic characteristics and differences of the two groups of respondents. Bad health status is more often found with the respondents in the group of those with the lower level of education and lower household income. Barring in mind that the level of education is one of the most important variables that 
explain nutrition knowledge, the results for the vulnerable group can be understood from the perspective of education of the respondents. Examining the additional question concerned with the existence of a chronic illness issue of other household member, the results are the same as the previous one.

\section{The importance of nutrition and food labeling}

In the next section we analyzed the perceived importance of nutrition and health labeling. Nutrition and health claims on food products are rated as a moderately important product attribute. More than $35 \%$ of the respondents say that NHCs on products are important for them, more than $45 \%$ express indifference to NHCs, while only $19 \%$ say that those claims are not important. There is a great number of respondents that do not have a positive attitude toward NHCs, which can be explained by two factors: (1) a high level of skepticism connected to food labels, already identified in the previous studies (Mitić, Gligorijević, 2012), (2) a low level of awareness and knowledge about those products. Our data confirmed that skepticism toward food labels influences attitudes toward the importance of NHCs. ${ }^{5}$ We found statistically significant differences between consumers that express different attitudes toward NH claims based on their attitudes toward truthfulness of food labels in general $(F=5.783 ; p=0.000)$. A higher level of confidence in the truthfulness of food labels influence a higher-perceived importance of NHCs on food products. Also, there is the statistical confirmation of a positive relationship between the level of knowledge and attitudes toward NHCs. A higher percentage of the respondents who expressed a lower level of nutrition knowledge rated NHCs as not important or proclaimed themselves as indifferent $(\mathrm{F}=9.526, \mathrm{p}=0.000)$, while in the group of the respondents who evaluated NHCs as very important majority of them (47.2\%) are those with the highest nutrition knowledge (comparing with $26.8 \%$ of consumers with the same level of nutrition knowledge who evaluated the importance of NHCs as not important at all).

In this segment of perceived importance of NHCs, we found statistically significant differences between the respondents based on gender ( $41.4 \%$ of female respondents highly rate importance of $\mathrm{NHCs}$, compared with $28.3 \%$ of male respondents; $t=-3.976, p=0.000$ ) and education (a larger percent of respondents with higher education valued the importance of NHCs on food products; $F=2.490, p=0.042$ ). There are no statistically significant differences regarding other socio-demographic factors, nor health related issues.

\section{Attitudes toward products with nutrition and health claims}

Consumers' attitudes toward products with NHCs were measured by five seven-point semantic differential scales with the following items: bad/good, unpleasant/pleasant, unhealthy/healthy, inconvenient for consumption/convenient for consumption, tasteless/ tasty and inexpensive/expensive. The results are in table 4. Attitudes toward products with nutrition and health claims are generally positive, with mean values above average. Statements that those products are good, healthy and expensive get the highest average marks, while statements that products are tasty get the lowest average mark. The taste of

5 In the second part of the questionnaire, among other attitudes toward food labels, we examined attitudes toward their truthfulness.

EP 2015 (62) 2 (335-352) 
these products can be seen as a potential obstacle for the increase in consumption, which will be examined in more detail in the next section. All in all, respondents have positive attitudes in all segments, which can be encouraging for producers, and which implies that there is a good potential for further development of Serbian market for products with NHCs.

Table 4. Attitudes toward products with NHCs

\begin{tabular}{|l|r|r|r|r|}
\hline In my opinion products with NHCs are: & \multicolumn{1}{|l|}{ Min. } & \multicolumn{1}{l|}{ Max. } & \multicolumn{1}{l|}{ Mean } & \multicolumn{1}{l|}{ Std. Deviation } \\
\hline bad/good & -3 & 3 & 1.74 & 1.318 \\
\hline unpleasant/ pleasant & -3 & 3 & 1.35 & 1.385 \\
\hline unhealthy/ healthy & -3 & 3 & 1.96 & 1.267 \\
\hline $\begin{array}{l}\text { inconvenient for consumption/ convenient } \\
\text { for consumption }\end{array}$ & -3 & 3 & 1.30 & 1.403 \\
\hline tasteless/ tasty & -3 & 3 & 1.09 & 1.528 \\
\hline inexpensive/ expensive & -3 & 3 & 1.55 & 1.355 \\
\hline
\end{tabular}

Source: Authors' calculation according to data from Mitić, Gligorijević, 2013.

Women have more positive attitudes (all six) than men (with statistically significant differences in the first three statements; statement $1: \mathrm{t}=-2.267, \mathrm{p}=0.024$, statement 2 : $\mathrm{t}=-2.043, \mathrm{p}=0.040$; statement $3: \mathrm{t}=-1.889, \mathrm{p}=0.059)$. With regard to education, age and income level, the only significant difference exists in the final statement. Respondents with lower income, lower level of education, and the oldest ones perceived those products as more expensive. Their socio-economic status has a high influence on the differences in the perception of the prices of those products. The most important variable can be the level of income, which is connected to the low level of education, due to small salaries of professions that do not require high education, and with the age of the respondents due to the fact that senior citizens are a socially vulnerable part of the population in Serbia.

Examining the differences in attitudes of the respondents based on their health status, we found more favorable attitudes toward products with NHCs among the respondents with better health (statistical significance for the first four statements, statement 1: $\mathrm{F}=7.265, \mathrm{p}=0.000$; statement 2: $\mathrm{F}=4.924, \mathrm{p}=0.001$; statement $3: \mathrm{F}=3.879, \mathrm{p}=0.004$; statement $4: \mathrm{F}=2.755$, $\mathrm{p}=0.027$ ). The differentiation of the consumers based on their chronic health problems gave the same results. Respondents without chronic illness have more positive attitudes (first four statements) toward products with $\mathrm{NHCs}$ (with statistically significant differences in: statement $1: \mathrm{t}=-3.124, \mathrm{p}=0.002$; statement $2: \mathrm{t}=-1.867, \mathrm{p}=0.062$; statement $4: \mathrm{t}=-2.022, \mathrm{p}=0.044)$.

\section{The consumption of products with nutrition and health claims}

Consumption of products with NHCs is tracked through three aspects: (1) attitudes toward the importance of consumption, (2) actual consumption of products and (3) intention to consume the products.

To some extent, we found a higher percent of the respondents that think that the consumption of products with $\mathrm{NHC}$ is important $(41.4 \%)$, in comparison with the attitude toward the importance of nutrition and health labeling of products, while $47 \%$ of the respondents are indifferent. There are no statistically significant differences between the respondents 
connected with their health conditions, economic status, age and gender. We only found differences between the respondents based on their education $(F=2.160, p=0.072$, respondents with higher education have more favorable attitudes toward the importance of consumption of products with $\mathrm{NHCs}$ ).

Regarding the consumption of products, we examined the frequencies of consumption. $56.1 \%$ of the respondents use this product at least once a week or more frequently. There is an evident gap between actual and intended consumption, as more than $77 \%$ of the respondents would use those products as frequently as they mentioned if they became more available. Availability of products with NHCs can be understood in the sense of prices and presence of products in distribution channels. The results of a study which tracked the presence of products with NHCs in retail stores in Serbia showed that those products are widely present in different retail formats and in many product categories (dairy, juices, sweets, bread and cereals, food for diabetics, etc.). Therefore, the mentioned gap can be the consequence of higher prices of products with NHCs, but also of the fact that consumers are not used to reading labels $(15.2 \%$ of the respondents regularly read labels on food products). Because of the absence of the habit to read labels, we can assume that consumers are not fully aware of the offer of the products with NHCs, and that can be highlighted as a significant difficulty for further increase in consumption. There are statistically significant differences based on demographic characteristics concerning actual consumption and intended consumption (table 5). Respondents with higher level of education, female respondents, respondents from households with higher economic standard and younger than 30 more frequently consume products with NHCs, and expressed to a larger extent the intention to use those product regularly (once a day and more) if they became more available.

It is possible to compare the differences between real consumption and intended consumption in the case of better availability of products. Although intended consumption is on a higher level than the actual one, in some cases those differences are very high. As expected, the respondents who are sensitive to price expressed higher willingness to regularly consume products with NHCs compared with their actual consumption. Those are the respondents from households with lower economic standards.

Table 5. Actual and intended consumption of products with NHCs

\begin{tabular}{|l|r|r|}
\hline \multicolumn{1}{|c|}{ Respondents' characteristics } & $\begin{array}{c}\text { Actual consumption of } \\
\text { products }\end{array}$ & $\begin{array}{c}\text { Intention to consume the } \\
\text { products }\end{array}$ \\
\hline Gender & $\mathrm{t}=2.979 ; \mathrm{p}=0.003$ & $\mathrm{t}=4.321 ; \mathrm{p}=0.000$ \\
\hline Education & $\mathrm{F}=10.813 ; \mathrm{p}=0.000$ & $\mathrm{~F}=3.639 ; \mathrm{p}=0.006$ \\
\hline Economic standard of households & $\mathrm{F}=7.929 ; \mathrm{p}=0.000$ & - \\
\hline Age & $\mathrm{F}=25.644 ; \mathrm{p}=0.000$ & $\mathrm{~F}=13.350 ; \mathrm{p}=0.000$ \\
\hline Vulnerable group/others & $\mathrm{t}=5.150 ; \mathrm{p}=0.000$ & $\mathrm{t}=4.249 ; \mathrm{p}=0.000$ \\
\hline Overall health status & $\mathrm{F}=11.919 ; \mathrm{p}=0.000$ & $\mathrm{~F}=8.562 ; \mathrm{p}=0.000$ \\
\hline
\end{tabular}

Source: Authors' calculation according to data from Mitić, Gligorijević, 2013. 
We also found significant differences between the respondents regarding their health status. As motioned before, we tracked health status of the respondents through two dimensions:

1. Overall health status:

- the respondents who evaluated their overall health as excellent more frequently use products with NHCs, compared to other respondents;

- in every group, more respondents expressed intention to buy products with NHCs if they became more available, compared to the number of respondents who already buy this products; the highest differences are in the groups of respondents with good and excellent health $(22 \%$ of the respondents with excellent health and $14.6 \%$ with good health) consume products with NHCs once a day and more, and 51\% (45.9\% with good health) would consume those products with the same frequencies if they became more available); in the case of the respondents with bad and very bad health they do not show such a high intention to consume products once a day and more.

2. Chronic health problems of the respondents:

- $\quad$ in the case of the vulnerable group of the respondents, in this segment we also got unexpected results, but in accordance with the results in previous sections; the vulnerable group do not consume products with NHCs as often as the respondents who do not have chronic health problems (statistically significant difference, $11.2 \%$ of the respondents in the vulnerable group consume the product once a day and more, comparing with $18.3 \%$ of the respondents in the non-vulnerable group);

- regarding the intention to consume products with NHCs, the results are in accordance with the previous - more respondents without health problems would consume those products more frequently if they became more available to them $(47.8 \%)$, comparing with the respondents in the vulnerable group $(36.3 \%)$; Looking at the initial level of consumption in both groups there is an increase in the intentions to consume the products, again with the highest increase in the group of respondents without health problems.

Further analysis will address the question of the main barriers that potentially inhibit the consumption of NHCs products. It seems that prices can be an important factor that influences buying behavior, which can be concerning given a potentially positive influence of the products with NHCs on health, especially in the case of the people with health issues. Apart from the prices, as potential obstacle for a higher consumption of the products with NHCs, we have already mentioned the absence of consumers' habit to read labels. The second issue that can explain the lower level of interest of the vulnerable group of the respondents is connected with their knowledge about the influences of the nutritional characteristics of food on health and their ability to understand the information presented on labels. 
Firstly, we will address the issue of the prices of food products as the determinants of consumers' behavior. Based on Food Choice Questionnaire (Steptoe et al., 1995), which is a part of the survey, we can evaluate the importance of price as a determinant of food choice and as a potential barrier for the consumption of the products with NHCs. The 36 items from the original FCQ were evaluated on a 5-item Likert scale. A principal component analysis with varimax rotation was performed. Nine factors were considered significant. They account for $57.12 \%$ of the variance (Table 6 ).

Table 6. Principal component analysis

\begin{tabular}{|c|c|c|c|c|}
\hline \multirow[b]{2}{*}{ Component } & \multicolumn{3}{|c|}{ Rotation Sums of Squared Loadings } & \multirow[b]{2}{*}{$\begin{array}{l}\text { Average factor } \\
\text { score } \\
\end{array}$} \\
\hline & Total & $\begin{array}{l}\text { \% variance } \\
\text { explained }\end{array}$ & Cumulative \% & \\
\hline $\begin{array}{l}\text { Health and nutrition value } \\
\text { of food }\end{array}$ & 4.034 & 11.207 & 11.207 & 4.03 \\
\hline Mood & 3.106 & 8.627 & 19.834 & 3.56 \\
\hline Weight control & 2.375 & 6.598 & 26.431 & 3.46 \\
\hline Convenience of preparation & 2.357 & 6.546 & 32.978 & 3.79 \\
\hline Sensory appeal & 2.221 & 6.168 & 39.146 & 4.39 \\
\hline Price & 1.718 & 4.773 & 43.919 & 3.74 \\
\hline Ethical concern & 1.636 & 4.546 & 48.464 & 2.77 \\
\hline Availability in shops & 1.567 & 4.352 & 52.816 & 4.30 \\
\hline Familiarity & 1.549 & 4.303 & 57.119 & 3.70 \\
\hline
\end{tabular}

Source: Authors' calculation according to data from Mitić, Gligorijević, 2013.

Based on the individual item scores, we found that the sensory appeal (4.39, on the fivepoint scale) (especially the taste of the food) is most important for food choice, next are the availability of food in retailing (4.30) and health/nutrition value of food (4.03). Consumers did not evaluate the price (items within this factor) as the most important factor of food choice, but it comes on the fifth place within nine factors, with an average mark 3.79. A deeper analysis shows that the vulnerable group of the respondents gives more importance to the items within the factor of prices, than the respondents without chronic health problems (statistically significant difference, Table 7). The same variation we found among the respondents with different overall health status.

This result confirms the previous statement that the behavior of the vulnerable group of the respondents can be explained by socio-demographic factors, especially by the level of income and education. This is why they value the prices of the products more comparing to the other groups, so the prices can be one explanation for their relatively low consumption of the products with NHCs. 
Table 7. The importance of prices regarding the health of the respondents

\begin{tabular}{|l|c|c|c|c|}
\hline \multirow{3}{*}{ Group of respondents } & \multicolumn{2}{|c|}{ Item $\mathbf{6}$} & \multicolumn{2}{|c|}{ Item 36 } \\
\cline { 2 - 4 } & \multicolumn{2}{|c|}{ "It is important to me that the food I eat on a typical } \\
day..."
\end{tabular}

Source: Authors' calculation according to data from Mitić, Gligorijević, 2013.

But, one question for discussion still remains- Why the vulnerable group did not express a higher level of intention to increase consumption, if those products became more available to them? Nutrition knowledge is the second potential barrier for consumers' consumption of products with NHCs. The level of knowledge differs significantly in different groups of respondents, regarding their actual and intended consumption of products with NHCs, awareness of those products, perceived importance of consumption and the presence of nutrition and health claims on the products.

Respondents that demonstrated a higher level of knowledge are those who (1) are better informed about those products $(\mathrm{F}=4.698, \mathrm{p}=0.009)$, as we pointed out that awareness is the prerequisite for knowledge, (2) assessed importance of NHCs on the product at a higher level ( $\mathrm{F}=9.526, \mathrm{p}=0.000)$, (3) perceived the consumption of products with $\mathrm{NHCs}$ as more important $(\mathrm{F}=9.671, \mathrm{p}=0.000)$, (4) used products with NHCs more often $(\mathrm{F}=4.309$, $\mathrm{p}=0.014)$, (5) expressed higher intended consumption $(\mathrm{F}=2.675, \mathrm{p}=0.069)$.

The results indicate that nutrition knowledge influences the perception of the importance of nutrition and health labeling, but also the consumption of those products. Consumers that know more about the characteristics of some nutrients, their natural sources and impact on health more regularly use products with NHCs. As the nutrition knowledge of vulnerable groups is not on a high level, that can partially explain their low actual consumption as well as the low level of intended consumption.

\section{Discussion and implications}

With the aim to explore various determinants of consumer food choice behavior, this quantitative study offers an additional insight into the characteristics of Serbian demand for products with nutrition and health labels. Examining consumers' awareness, attitudes, knowledge and consumption we found significant differences based on socio-demographic characteristics of the respondents. As in some previous studies, we found positive relations between awareness, attitudes and consumption, on one side, and the level of education and the level of income, on the other. Also, women have more positive attitudes toward products with NHCs than men. 
Apart from socio-demographic characteristics, we introduced additional variables that describe the health status of the respondents. Respondents with chronic health problems (the vulnerable group), and overall worse health status, showed a lower level of awareness and consumption of the products with NHCs. Those results represent an important finding, significant for producers, but also for government institutions and health organizations. As nutrition is an important part of medical treatment of chronic health problems, those results reveal the necessity to provide additional instructions and information to the vulnerable group. From the perspective of producers, we can recommend highlighting potential positive effect of their products' nutrients on health through advertising and other promotion tools, in order to build better awareness and improve nutrition knowledge of consumers. The role of the government, professional organizations, educational, public and medical institutions in improving the nutrition knowledge of consumers in Serbia, either through a national government campaign or specialized educational programs developed by educational or medical institutions is essential.

A low level of nutrition knowledge is a general characteristic of Serbian consumers, but the lowest level of knowledge is in the group of the respondents with some health problems. This can be the most important reason for the low level of awareness and consumption of products with NHCs, but also of a lower intention to consume them (if they become more available to them). In order to examine food choice behavior characteristics of the vulnerable group of the respondents in more detail, we identified their food buying motives as well as their attitudes toward food labels as potential barriers for the increase in consumption. Basic food motives appear to be sensory appeals, especially the taste of food, which is in accordance with the results of the majority of studies in this field. Regarding other food choice motives, the vulnerable group value prices of food as more important than the group of the respondents without health problems. Food motives can be one of the restraining factors for the rise in consumption, having in mind that products with NHCs have a different taste from the regular products (especially in the case of products with the reduced level of fat, sugar or salt) and that lower economic status of the vulnerable group influences their higher price sensitivity. When it comes to food label usage, consumers in Serbia, in general, do not read labels regularly, which can be an obstacle for a better market positioning of producers, as well as for the increase in consumption, especially by the vulnerable group. The absence of the habit to read labels and a high level of skepticism of Serbian consumers, identified in some previous studies, can be the result of the low level of knowledge, but also of the absence of comprehensive regulation in the segment of nutrition and health claims. An extensive usage of those claims, particularly of the general and misleading claims, can develop the intolerance effect. The improvement of Serbian legislation, and further harmonization with the EU regulations, will certainly have a positive impact on consumers' attitudes and confidence in food labeling and health claims on food products.

Based on the whole sample, we found that knowledge and socio-demographic characteristics of consumers are important variables of food choice in the segment of products with nutrition and health claims. These characteristics of the consumers make a distinction between users and non-users of those products, with evident differences in attitudes, awareness, consumption, 
perceived importance of nutrition and health labeling, and in other analyzed segments. The increase in knowledge, especially in the case of the vulnerable groups, as well as in education and income, could have a positive impact on the consumption of the products with nutrition and health claims.

\section{Literature}

1. Baltas, G. (2001):The effects of nutrition information on consumer choice, Journal of Advertising Research, vol. 35, no. 5/6, pp. 57-63.

2. Bornkessel, S., Bröring, S.,Omta, S.W.F., van Trijp, H. (2014): What determines ingredient awareness of consumers? A study on ten functional food ingredients, Food Quality and Preference, no. 32, pp. 330-339.

3. Chan, C., Patch, C., Williams, P. (2005): Australian consumers are sceptical about but influenced by claims about fat on food labels, European Journal of Clinical Nutrition, vol. 59, pp. 148-151.

4. Ford, G., Hastak, M., Mitra, A., Ringold, D. (1996): Can Consumers Interpret Nutrition Information in the Presence of a Health Claim? A Laboratory Investigation, Journal of Public Policy \& Marketing, vol. 15, no. 1, pp. 16-27.

5. Gagić, S., Jovičić, A., Tešanović, D., Kalenjuk, B. (2014): Motives for food choice among Serbian consumers, Economics of Agriculture, vol. 61, no. 1, pp. 41-51.

6. Health claims, EU Commission, Brussels, Belgium, available at: http:/lec.europa.eu/ food/food/labellingnutrition/claims/ health claims en.htm

7. Health and nutrition claims, European Commission, Brussels, Belgium, available at: http://ec.europa.eu/food/food/labellingnutrition/claims/index_en.htm

8. Kozup, J., Creyer, E., Burton, S. (2003): Making Healthful Food Choices: The Influence of Health Claims and Nutrition Information on Consumers' Evaluations of Packaged Food Products and Restaurant Menu Items, Journal of Marketing, no. 67, pp. 19-34.

9. Lalor, F., Kennedy, J., Flynn, M., Wall, P. (2010): A study of nutrition and health claims - a snapshot of what's on the Irish market, Public Health Nutrition, vol. 13, no. 5, pp. $704-711$.

10. Milošević, J., Žeželj, I., Gortonc, M.,Barjolle, D. (2012): Understanding the motives for food choice in Western Balkan Countries, Appetite, vol. 58, no. 1, pp. 205-214.

11. Mitić, S., Gligorijević, M. (2012): Consumers'attitudes towards nutrition labeling and health claims on food products in Serbia, $3^{\text {rd }}$ EMAC CEE Regional Conference, September 12-14, Belgrade, Faculty of Economics, University of Belgrade, pp. 83-89.

12. Mitić, S., Gligorijević, M., Zečević, A. (2013): Istraživanje ponude prehrambenih proizvoda sa zdravstvenim i nutritivnim izjavama, Ekonomska politika i razvoj (Eds: Jovanović Gavrilović, B., Rakonjac Antić, T., Stojanović, Ž., Filipović, M., Ekonomski fakultet, Univerzitet u Beogradu, Beograd, pp. 55-79. 
13. Mitić, S., Gligorijević, M. (2013): Project no. III 41030 - Biological mechanism, nutrition intake and status of polyunsaturated fatty acids and folates: section 5 - Nutrition and consumers, survey research, internal documentation (questionnaires), Faculty of Economics, Belgrade University.

14. Næs, T., Kubberød, E., Sivertsen, H. (2001): Identifying and interpreting market segments using conjoint analysis, Food Quality and Preference, no. 12, pp. 133-143.

15. Niva, M. (2006): Can we predict who adopts health-promoting foods? Users of functional foods in Finland, Scandinavian Journal of Food and Nutrition, no. 50, pp. 1324.

16. Niva, M.,Mäkelä, J. (2005): Finns and functional foods: socio-demographics, health efforts, notions of technology and the acceptability of health-promoting foods, International Journal of Consumer Studies, vol. 31, no. 1, pp. 34-45.

17. Regulation (EC) No 1924/2006 of the European parliament and of the Council, 20 December 2006, Bruxelles, Belgium, available at: http://eur-lex.europa.eu/legal-content/en/ txt/pdf/?uri=celex:3200 6r1924\&from $=$ en

18. Roos, E. (1998): Gender, socioeconomic status and family status as determinants of food behavior, Social Science and Medicine, vo. 46, pp. 1519-1529.

19. Sanlier, N., Karakus, S. (2010): Evaluation of food purchasing behaviour of consumers from supermarkets, British Food Journal, no. 112, pp. 140-150.

20. Shimizu, T. (2003): Health Claims and Scientific Substantiation of Functional Foods Japanese System Aiming the Global Standard, Current topics in Nutraceutical Research, vol. 1, no. 2, pp. 1-12.

21. Shine, A., O'Reilly, S., O’Sullivan, K. (1997): Consumer use of nutrition labels, British Food Journal, vol. 99, no. 8, pp. 290-296.

22. Steptoe, A., Pollard, T., Wardle, J. (1995): Development of a measure of the motives underlying the selection of food: The food choice questionnaire, Appetite, no. 25, pp. $267-$ 284.

23. Stojanović, Ž., Dragutinović Mitrović, R. (2012): The Serbian Functional Food Market: Does Regulation Make a Difference?, Economic Annals, vo. 57, no. 193, pp. 53-69.

24. Stojanović, Ž., Ognjanov, G.,Dragutinović Mitrović, R. (2010): Nutritional \& Health Claimed Products Market Development in Serbia: Exploration of Findings Obtained

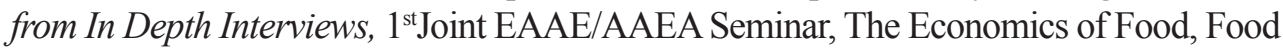
Choice and Health, September 15-17, Freising, Germany.

25.Žeželj, I., Milošević, J., Stojanović, Ž., Ognjanov, G. (2012): The motivational and informational basis of attitudes toward foods with health claims, Appetite, vol. 59, no. 3 , pp. $960-967$. 


\title{
STAVOVI, ZNANJE POTROŠAČA I POTROŠNJA PROIZVODA SA NUTRITIVNIM I ZDRAVSTVENIM IZJAVAMA
}

\author{
Sanja Mitic ${ }^{6}$, Mirjana Gligorijevic ${ }^{7}$
}

\begin{abstract}
Rezime
U ovom radu su predstavljeni rezultati istraživanja ponašanja potrošača u Srbiji u segmentu hrane. U radu je fokus na proizvodima sa nutritivnim i zdravstvenim izjavama (NZI) $i$ na analizi ključnih karakteristika potrošača koje utiču na svest o ovim proizvodima, nutritivno znanje, stavovima i kupovnim namerama. Analizirani su različiti socio-demografski faktori koji utiču na ponašanje potrošača. Ključni faktori koji utiču na svest, znanje i potrošnju su: obrazovanje, pol, starost i dohodak. Kako su proizvodi sa NIZ povezani sa zdravljem potrošača, u radu su istražene $i$ razlike u ponašanju sa aspekta zdravstvenog stanja ispitanika. Rezultati pokazuju da ispitanici sa zdravstenim problemima ređe koriste ove proizvode u odnosu na druge ispitanike, što je posledica lošijeg nutritivnog znanja. Ovo je ključna prepreka za povećanje potrošnje. Na kraju će biti date preporuke za mendžere, u cilju prevazilaženja identifikovanih prepreka, kao i za državne institucije, kako bi bilo moguće unaprediti opšte zdravlje populacije.
\end{abstract}

Ključne reči: zdravstvene izjave, nutritivne izjave, oznake na hrani, nutritivno znanje, ponašanje potrošača.

6 Doc. dr Sanja Mitić, Ekonomski fakultet, Univerzitet u Beogradu, Kamenička 6, Beograd,Srbija, Telefon: +381113021175, E-mail: sanja@ekof.bg.ac.rs

7 Prof. dr Mirjana Gligorijević, redovan profesor, Ekonomski fakultet, Univerzitet u Beogradu, Kamenička 6, Beograd, Srbija, Telefon: +381113021019, Email: miragli@sezampro.rs 